\title{
Workplace Stress - Causes of Work Place Stress in Police Department: A Proposal for Stress Free Workplace
}

\author{
Smt.Rashmi Hunnur ${ }^{1}$, Dr.M.M.Bagali ${ }^{2}$, Dr.S Sudarshan ${ }^{3}$ \\ ${ }^{I}$ (Research Scholar, Jain University, Bangalore, and working as Asst.Professor, Department of Management \\ Studies, Basaveshwar Engineering College, Bagalkot, Karnataka, India) \\ ${ }_{2}^{2}$ (Research Coordinator, Research in Management, Jain University, Bangalore, India) \\ 3 (Jain University, Bangalore, India)
}

\begin{abstract}
Police Department is one of the important department for societal wellbeing. Police have to work round the clock to keep public safe. Throughout the day they are doing a restless job. They don't have week end holiday and occasional holiday. In fact, on those days they have to work even harder in the name of bandhubast duty. Because of this they are not getting time to spend with their family members, which leads to frustration. Further, this frustration may manifest as depression and they will lose interest in their job. If we keenly observe, out of 100 police men $80 \%$ of them will be having procrastinating attitude, impatience, and irritability etc which are the symptoms of Stress. And nowadays the suicide attempts are also on the rise in police department. Role overload, role conflict, role ambiguity, poor peer relations, low status etc., are the key variables for the research problem. The present study will help to develop more appropriate strategies to cope with workplace stress and that these could be incorporated into a more fully integrated set of human resource policies for better performance of police department in the study region.
\end{abstract}

Keywords: role ambiguity, role conflict, role overload

\subsection{STRESS:}

\section{Introduction}

The word stress was borrowed into the social sciences from the field of engineering and physics. In physics, it represents the internal force generated within a solid body in response to the action of an external force distorting the body. While the external force was called 'lead', the resulting distortion came to be known as 'strain'. Hans Selye (1936)[1], known as "The father of modern stress", brought to our attention, the concept of stress in a medical sense to indicate overloading of the human body.

Stress is thus any non-specific response of the body to any demand made upon it. "All agents that we come into contact with, produce a non-specific increase in the need to perform adaptive functions and thereby to reestablish normalcy. It does not matter if the agent or situation we face were pleasant or unpleasant; all that counts are the intensity of the demand for readjustment or adaption" noted Selye in (1974)[2].

Stress is our body's way of responding to additional demands. It can be caused by both good and bad experiences. When people feel stressed by something going on around them, their bodies respond by releasing chemicals into the blood stream. These chemicals give people more energy and strength, which might be a good thing if physical danger is a possibility. This can, however, be a negative trigger, if their stress is in response to something emotional and there is no outlet to release this additional energy and strength.

\subsection{OCCUPATIONAL STRESS:}

Stress may be classified into eustress and distress. Eustress is positive or good stress, whereas distress is the stress reactions to those events or actions appraised as being negative. Stress-related disorders encompass a broad array of conditions, including psychological disorders (e.g., depression, anxiety, post-traumatic stress disorder) and other types of emotional strain (e.g.,dissatisfaction, fatigue, tension, etc.), maladaptive behaviors (e.g., aggression, substance abuse), and cognitive impairment (e.g., concentration and memory problems). In turn, these conditions may take the form of poor work performance, higher absenteeism, less work productivity or even injury. Job stress is also associated with various biological reactions that may lead ultimately to compromised health, such as cardiovascular disease, or in extreme cases, even death.

There are a total of 5 categories associated with occupational stress, Viz:

a. $\quad$ Factors unique to the job

b. $\quad$ Role in the organization

c. Career development

d. Interpersonal work relationships

e. Organizational Structure/climate

These individual categories demonstrate that stress can occur specifically when a conflict stems from the job 
Workplace Stress - Causes of Work Place Stress in Police Department: A Proposal for Stress Free

demands placed by the employer and the employee himself. If not handled with care, the stress can become distress (medicine). The first category is related to the ability of the employee coping with the specific hours worked, the level of productive rate expected the physical environment, as well as the expectancy of the work desired by management. For instance, research demonstrates that night shifts in particular have a high tendency of adverse reaction towards the health of the employee. In relation to this, approximately 20 percent of night shift workers have experienced psycho-physiological dysfunctions, including heart diseases. Extreme factors can affect the competence levels of employees. The second category, role in the organization, is associated with the hierarchical ranking of that particular employee within the organization. Upper management is entitled to oversee the overall functioning of the organization. This cause's potential distress as the employee must be able to perform simultaneous tasks. With the third category, career development, other factors come into play. Securities of their occupation, promotion levels, etc. are all sources of stress, not to mention the ever-changing market, technology, and scale of economic dominance. The fourth category of workplace stress pertains to the interpersonal relationships within the workplace. The workplace is a communication and interaction minefield. These relationships (either developed or developing) can be problematic or positive. Common stressors include harassment, discrimination, biased opinions, hearsay, and other derogatory remarks. Finally, the last category of workplace stress is the organizational climate or structure. The overall communication, management style, and participation among groups of employees are variables to be considered. In essence, the resultant influence of the high participation rate, collaborative planning, and equally dispersed responsibilities provides a positive effect on stress reduction, improved work performance, job satisfaction, and decreased psychosomatic disorders.

\subsection{CAUSES OF STRESS}

Many different things can cause stress -- from physical (such as fear of something dangerous) to emotional (such as worry over your family or job). Identifying the causes of stress is often the first step in learning how to reduce one's stress. Some of the most common sources of stress are:

1.3.1 Survival Stress - One may have heard the phrase "fight or flight". This is a natural response to danger among people and animals alike. When one is fearful of someone or something physically hurting you, your body naturally responds with a burst of energy so that you will be better able to survive the dangerous situation (fight) or escape it all together (flight). This is survival stress.

1.3.2 Internal Stress - Have you ever caught yourself worrying about things you can do nothing about or worrying for no reason at all? This we call internal stress and are one of the most important forms of stress to detect and manage. Internal stress is when people make themselves stressed. This often happens when we worry about things we can't control or put ourselves in situations we know will cause us stress. Some people relish the hurried, tense lifestyle that results from being under stress. They even yearn for stressful situations and feel stress about things that aren't stressful.

1.3.3 Environmental Stress - This is a response to things around you that cause stress, such as noise, crowding, and pressure from work or family. Identifying these environmental stresses and learning to avoid them or deal with them effectively will help reduce your stress level.

1.3.4 Fatigue and Overwork - This kind of stress builds up over a long time and can take a heavy toll on your body. It can be triggered by working too much or too hard at your job(s), school, or home. It could also be caused by not knowing how to manage your time efficiently or not taking time off for rest and relaxation. This can be one of the hardest kinds of stress to avoid because many people feel this is out of their control. Later in the course, we will discover various options and offer some useful tips for dealing with fatigue.

\subsection{THE EFFECTS OF STRESS}

- Stress can cause chronic fatigue, digestive ailments, headaches, and back pain.

- Stress can affect the blood cells that help you fight off infection, so you are more prone to be infected by colds or other diseases.

- Constant stress can elevate blood pressure and can increase the risk for stroke.

- Stress can increase the occurrence of heart attacks particularly if you are often angry and mistrustful.

- Stress can make an asthma attack worse.

- Stress triggers behaviors that contribute to death and disability, such as smoking, alcoholism, drug abuse, and overeating.

- Stress can lead to diminished sexual desire and an inability to achieve orgasm.

- Stress makes it harder to take remedial steps to rejuvenate health, such as giving up smoking or making better dietary choices. 


\subsection{WHY STRESS STUDY IN POLICE DEPARTMENT}

Police officers play a very significant role for maintaining law and order in the society despite all the shortcomings and limitations in the Police Department especially with regard to the infrastructure facilities, manpower and periodic training. Police Officers are supposed to implement all the criminal laws for which they work round the clock and / or without any leave/break, which cause tremendous mental pressure and physical exertion on them. As a result a few of them may have violent outbursts.

According to National Police Suicide Foundation, every 22 hours, a police officer in America takes his or her own life. This leads to the inevitable conclusion that police officers are not able to cope well with job-related stress.

\section{Literature Review}

A research on Police Stress: A Study of The Melvindale Police Department, by Christopher A. Barbb, Michigan, (2003)[3] states that Police officers are more susceptible to stress related problems than the general population due to the very nature of their work. Police officers are exposed to various traumatic experiences during their tours of duty. Officers are also faced with making life and death decisions that can create a great deal of stress. The results indicate that officers do indeed suffer from stress and its effects. Stress in the workplace can be a threat to employee health and well being. Peterson (1995)[4] explored role conflict, role ambiguity and role overload as reported by industrial workers and also found that managers are more stressed due to role overload from his study "organizational issues for managers". Upadhyay and Singh (1999)[5] compared the level of occupational stress experienced by the 20 college teachers and 20 executives. The executives showed significant higher levels of stress than college teachers on role over load, role ambiguity, role conflicts factor. Hasnain et al. (2001)[6] on his study "role stress and coping strategies in different occupational groups" assessed the coping strategies in three different occupational groups (20 engineers, 20 managers and 20 teachers). Role over load and role erosion were found to be major sources of role stress in all three groups. Pandey and Tripathy (2001)[7] also found that teaching is a stressful occupation. Job stressors in this profession are role ambiguity and unreasonable group pressure. Bhattacharya and Guha (2006)[8] conducted a study on stress and coping: A study on lady criminal lawyers of Kolkata city. A group of 34 lady criminal lawyers were selected for the study. The significant factors responsible for stress are busy schedule of work, odd duty hours, poor interaction, leading tendency of superiors, and poor interpersonal relationship among the colleagues in the work environment.

A research on "Workplace stress - Factors that contribute to workplace stress", undertaken by Maria Parkinson (2010)[9], concludes that the workplace stress is becoming a major problem in today's society. A quarter of employees view their job as the major stress in their lives. Several factors contribute to workplace stress like one factor is longer working hours. She also says that police officers reported more suicidal thoughts than the general population. Policing is an inherently psychologically stressful job where officers face danger, possible death, violence and very high demands.

A research on "Toxic Work", by Barbara B. Reinhold, (1996)[10] says that stress increased a person's susceptibility to illness such as heart attacks, high blood pressure, back pain, fatigue, and cancer.

According to the report prepared by Sibnath Deb, Tanusree Chakraborty, Pooja Chatterjee and Neerajakshi Srivastava (2008)[11] titled "Are West Bengal Police Officers Stressed", Police officers play a very significant role protecting law and order in the society despite all the shortcomings and limitations in the Police Department especially in regard to the infrastructure facilities, manpower and periodic training, the Police Officers are expected to implement all the criminal laws for which they work round the clock and / or without any leave/break, which cause tremendous mental pressure and physical exertion on them. As a result a few of them may have violent outbursts.

A article on "Police stress Research" prepared by NIOSH working group, The Indian Police Journal, (2004)[12], reveals that according to the National Police Suicide Foundation, every 22 hours, a police officer in America takes his or her own life. This leads to the inevitable conclusion that police officers are not able to cope adequately with job-related stress.

Area covered for study: Bagalkot, Bijapur, Belgaum, and Dharwad districts

TABLE 1: Showing the population in 2011 against 2001 for Bagalkot, Belgaum, Dharwad, and Bijapur districts

$$
\text { Karnataka - 6,11,30,704 }
$$
$5,30,50,562$

\begin{tabular}{|c|c|c|}
\hline District & Population 2011 & Population 2001 \\
\hline Bagalkot & $18,90,826$ & $16,51,892$ \\
\hline Belgaum & $47,78,439$ & $42,14,505$ \\
\hline Dharwad & $18,46,993$ & $16,04,253$ \\
\hline Bijapur & $21,75,102$ & $18,06,918$ \\
\hline
\end{tabular}


Workplace Stress - Causes of Work Place Stress in Police Department: A Proposal for Stress Free

\begin{tabular}{|c|c|c|}
\hline TOTAL & $1,06,91,360$ & $92,77,568$ \\
\hline
\end{tabular}

Source: India Population 2001 and 2011, from Spardha Spoorthi-May 2011, Kannada Magazine

TABLE 2: Showing the total number of police stations in Belgaum Range

\begin{tabular}{|c|c|}
\hline District & Number of Police Stations \\
\hline Bagalkot & 19 \\
\hline Belgaum & 42 \\
\hline Dharwad & 42 \\
\hline Bijapur & 22 \\
\hline TOTAL & $\mathbf{1 2 5}$ \\
& (Excluding Traffic, DSB DPO, DCRB DPO, FPU DPO, PI(Exercise)) \\
\hline
\end{tabular}

TABLE 3: Showing the total police strength of Belgaum Range

\begin{tabular}{|c|c|c|c|c|c|c|}
\hline \multirow[t]{2}{*}{ District } & \multicolumn{2}{|c|}{ Sanctioned Strength } & \multicolumn{2}{|c|}{ Present Strength } & \multicolumn{2}{|c|}{ Vacancy } \\
\hline & $\mathrm{HC} / \mathrm{WHC}$ & $\begin{array}{c}\mathrm{PC} / \\
\mathrm{WPC}\end{array}$ & $\begin{array}{c}\mathrm{HC} / \\
\mathrm{WHC}\end{array}$ & $\begin{array}{c}\mathrm{PC} / \\
\mathrm{WPC}\end{array}$ & $\begin{array}{c}\mathrm{HCl} \\
\mathrm{WHC}\end{array}$ & $\begin{array}{c}\mathrm{PC} / \\
\mathrm{WPC}\end{array}$ \\
\hline Bagalkot & 213 & 705 & 202 & 684 & 11 & 21 \\
\hline Dharwad & 132 & 270 & 114 & 227 & 18 & 43 \\
\hline Bijapur & 286 & 811 & 284 & 704 & 2 & 107 \\
\hline Belgaum & 577 & 1496 & 522 & 1276 & 55 & 220 \\
\hline Total & 1208 & 3282 & 1122 & 2891 & & \\
\hline Total vacancy & & & & & 86 & 391 \\
\hline
\end{tabular}

Total $\mathrm{HC}+\mathrm{PC}=1122+2891=4013$

As per State Police Government Policy, one constable should handle 1800 people. i.e., 1:1800. But as per present strength of constables (4013), each constable is handling 2,664 people.

i.e., Total Population / Total HC\& PC Strength

i.e., $(1,06,91,360 / 4013)=2,664.18$

i.e., $2,664-1,800=864$

Other than 1800 , extra 864 people each constable in handling.

All this man power statistics says that, there are insufficient human resource in the department which is again one of the major cause for stress.

Hence, the study is to find out the causes of stress and level of stress among the Head Constables / Police Constables in Police Department. It is with the interaction, maturity, and the critical understanding that, the lower range of police department personnel faces stress due to the job, per se.

\section{A PILOT STUDY}

\section{Research Methodology}

A pilot study is carried before the actual study to establish the feasibility of the study and to identify any problems that may exist (Mauch \& Birch; 1998). The questionnaire was distributed to 60 respondents in Bagalkot district of Karnataka State, before the actual study commenced. The newly crafted district, with a population of around 18,90,826 (Censes 2011), was the study area.

Sample for pilot study:

TABLE 4: Showing the sample for pilot survey

\begin{tabular}{|c|c|c|c|c|c|}
\hline Occupation & Bagalkot & Amingad & Ilkal & Hungund & Total \\
\hline HC/PC & 20 & 10 & 15 & 15 & 60 \\
\hline
\end{tabular}

The respondents were asked to identify any problems that they may have had with the questionnaire. After a discussion with these respondents and as well as discussion with the higher grade police officers (Police Inspectors, Deputy Superintendent of Police), the questionnaire was amended and the consequent concerns or additional contributions were taken into consideration.

\section{THE RESEARCH SAMPLE}

The study was conducted in 4 districts of Karnataka i.e., Bagalkot, Bijapur, Belgaum, and Dharwad. The total strength of $\mathrm{HC}$ and $\mathrm{PC}$ in four districts is 4013 . Hence, the sample size is 475.

TABLE 5: Showing the research sample

\begin{tabular}{|c|c|c|c|c|c|}
\hline Occupation & Bagalkot & Bijapur & Belgaum & Dharwad & Total \\
\hline HC/PC & 217 & 131 & 67 & 60 & 475 \\
\hline
\end{tabular}


Occupational Stress Index is used which tells us about the relevant components causing stress in the department, as well as the dimensions used in the scale are very relevant to the working conditions in the police department. This index examines 12 particular dimensions: role overload, role ambiguity, role conflict, Unreasonable group $\&$ political pressure, responsibilities for persons, under participation, powerlessness, poor peer relations, intrinsic impoverishment, low status, strenuous working conditions, and unprofitability.

\section{Analysis}

TABLE 6: Showing Descriptive Statistics of Occupational Stress Index for HC/PC

\begin{tabular}{|lccccc|}
\hline Descriptive statistics & $\mathrm{N}$ & Minimum & Maximum & Mean & Std. Deviation \\
\hline Role Overload & 475 & 8.00 & 25.00 & 18.49 & 3.49 \\
\hline Role Ambiguity & 475 & 4.00 & 20.00 & 11.89 & 2.89 \\
\hline Role Conflict & 475 & 6.00 & 24.00 & 14.75 & 2.92 \\
\hline $\begin{array}{l}\text { Unreasonable group and political } \\
\text { pressure }\end{array}$ & 475 & 6.00 & 20.00 & 14.12 & 3.13 \\
\hline Under participation & 475 & 3.00 & 15.00 & 10.25 & 2.65 \\
\hline Powerlessness & 475 & 1.00 & 5.00 & 3.41 & 1.14 \\
\hline Poor peer relations & 475 & 4.00 & 17.00 & 11.09 & 1.86 \\
\hline Intrinsic impoverishment & 475 & 4.00 & 20.00 & 12.01 & 2.86 \\
\hline Low status & 475 & 3.00 & 15.00 & 8.25 & 2.65 \\
\hline Strenuous working conditions & 475 & 5.00 & 20.00 & 13.35 & 3.22 \\
\hline Unprofitability & 475 & 2.00 & 10.00 & 6.90 & 1.74 \\
\hline Occupational Stress Index & 475 & 75.00 & 183.00 & 121.68 & 22.13 \\
\hline
\end{tabular}

GRAPH 1: Showing Descriptive Statistics of Occupational Stress Index for HC/PC

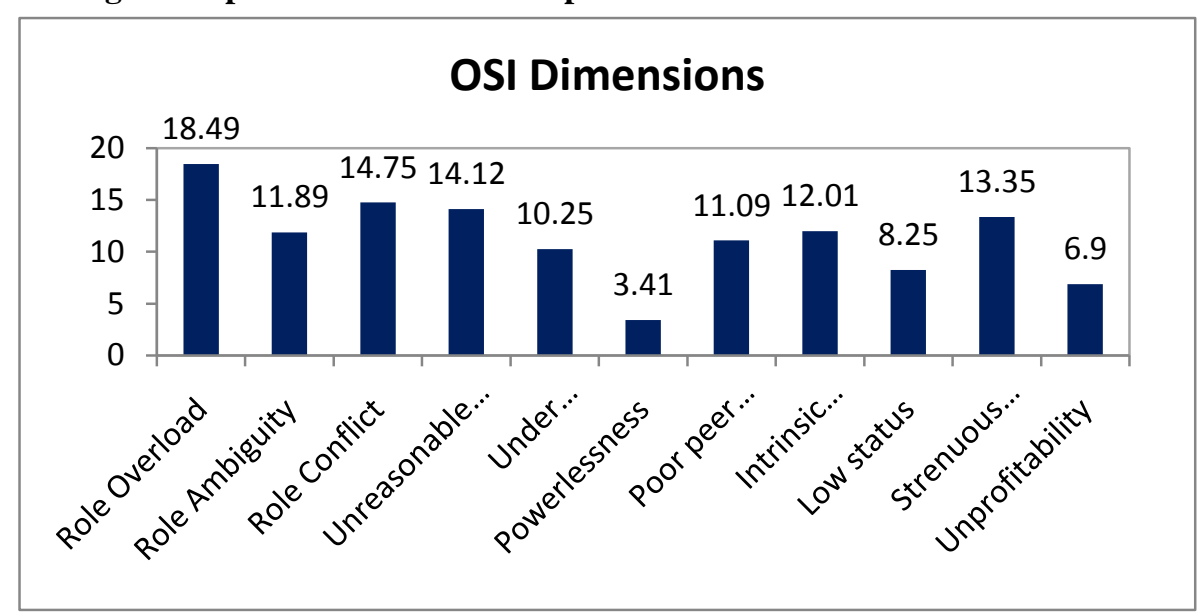

The descriptive statistics of occupational stress assessed from 11 dimensions is given above. The maximum and minimum scores, mean and standard deviation are given in the above table. It can be observed that among the minimum scores, 'Powerlessness' is scored least followed by 'Low status' scoring 1 . The highest score is 8 for 'Role overload'. When the maximum scores are compared, the least score of 5 is for 'Powerlessness' and the highest score of 25 is for 'Role overload' and other dimensions have scores in between. The average score is Highest for 'Role overload' 18.49 with the highest standard deviation 3.49 and the least is for 'Powerlessness' with mean 3.41 and least Standard deviation 1.14. The Overall Stress Index has a mean score 121.68 with standard deviation 22.13 .

TABLE 7: Showing Occupational Stress Index Score for HC/PC

\begin{tabular}{|lr|c|}
\multicolumn{1}{|c|}{ Low } & High \\
\hline Role Overload & $14.9 \%$ & $85.1 \%$ \\
\hline Unprofitability* & $16.6 \%$ & $83.4 \%$ \\
\hline Under participation & $18.3 \%$ & $81.7 \%$ \\
\hline Powerlessness* & $27.4 \%$ & $72.6 \%$ \\
\hline Unreasonable group and political pressure & $34.7 \%$ & $65.3 \%$ \\
\hline Strenuous working conditions & $39.8 \%$ & $60.2 \%$ \\
\hline Intrinsic impoverishment & $44.4 \%$ & $55.6 \%$ \\
\hline Role Conflict & $56.8 \%$ & $43.2 \%$ \\
\hline
\end{tabular}




\begin{tabular}{|lll|}
\hline Poor peer relations & $57.3 \%$ & $42.7 \%$ \\
\hline Role Ambiguity & $63.4 \%$ & $36.6 \%$ \\
\hline Low status & $67.2 \%$ & $32.8 \%$ \\
\hline Occupational Stress Index & $14.5 \%$ & $85.5 \%$ \\
\hline
\end{tabular}

*Less number of items

GRAPH 2: Showing Occupational Stress Index Score for HC/PC

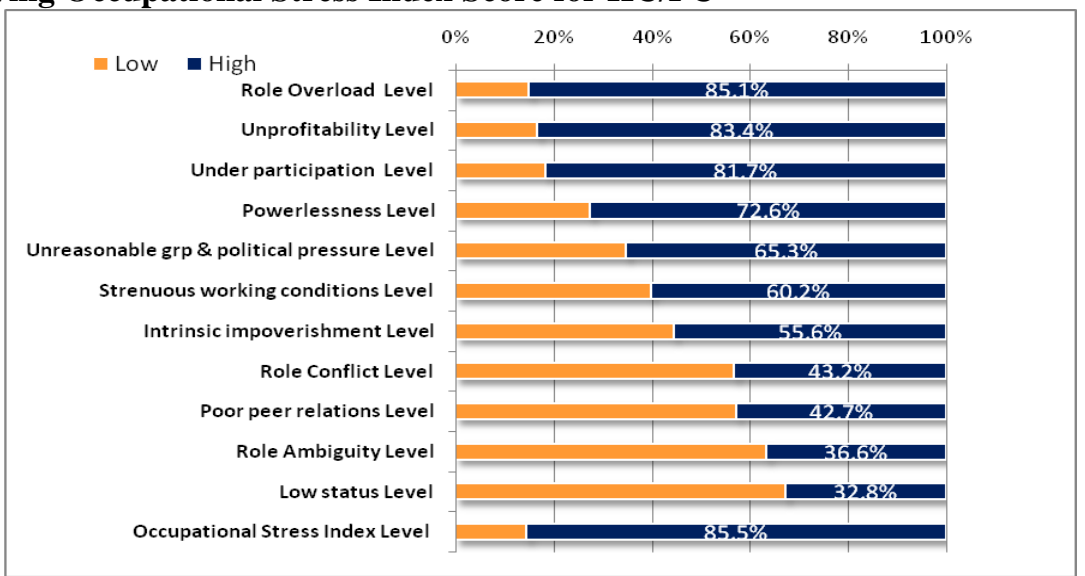

The above graph shows the dimensions which are causing high stress. Role overload $85.1 \%$, unprofitability $83.4 \%$, under participation $87.1 \%$, powerlessness $72.6 \%$, unreasonable group and political pressure $65.3 \%$, strenuous working conditions $60.2 \%$ and intrinsic impoverishment $55.6 \%$. These are the major dimensions which are causing high stress among the HC/PC of police department. Overall Occupational Stress Index has shown $85.5 \%$ high stress in Police Department.

TABLE 8: Showing Occupational Stress Index Level in HC/PC

\begin{tabular}{lcc}
\hline \multicolumn{1}{c}{ Occupational Stress Index Level } & Frequency & Occupational Stress Index Level \\
\hline LOW OSI & 69 & 14.5 \\
HIGH OSI & 406 & 85.5 \\
Total & 475 & 100.0 \\
\hline
\end{tabular}

Table 9: Showing OSI Dimensions Score with Cut off Score for HC/PC

\begin{tabular}{|lccc|} 
& OSI Mean & $\begin{array}{c}\text { OSI cut off } \\
\text { Score }\end{array}$ & $\begin{array}{c}\text { Std. Deviation } \\
\text { Role Overload }\end{array}$ \\
\hline Role Ambiguity & 18.49 & 14 & 3.49 \\
\hline Role Conflict & 11.89 & 12 & 2.89 \\
\hline Unreasonable group and political pressure & 14.75 & 15 & 2.92 \\
\hline Under participation & 14.12 & 12 & 3.13 \\
\hline Powerlessness & 10.25 & 7 & 2.65 \\
\hline Poor peer relations & 3.41 & 2 & 1.14 \\
\hline Intrinsic impoverishment & 11.09 & 11 & 1.86 \\
\hline Low status & 12.01 & 11 & 2.86 \\
\hline Strenuous working conditions & 8.25 & 9 & 2.65 \\
\hline Unprofitability & 13.35 & 12 & 3.22 \\
\hline Occupational Stress Index & 6.90 & 5 & 1.74 \\
\hline Distance from Base (\%) & 121.68 & 97 & 22.13 \\
\hline
\end{tabular}




\section{Graph 3: Showing OSI Dimensions Score with Cut off Score for HC/PC}

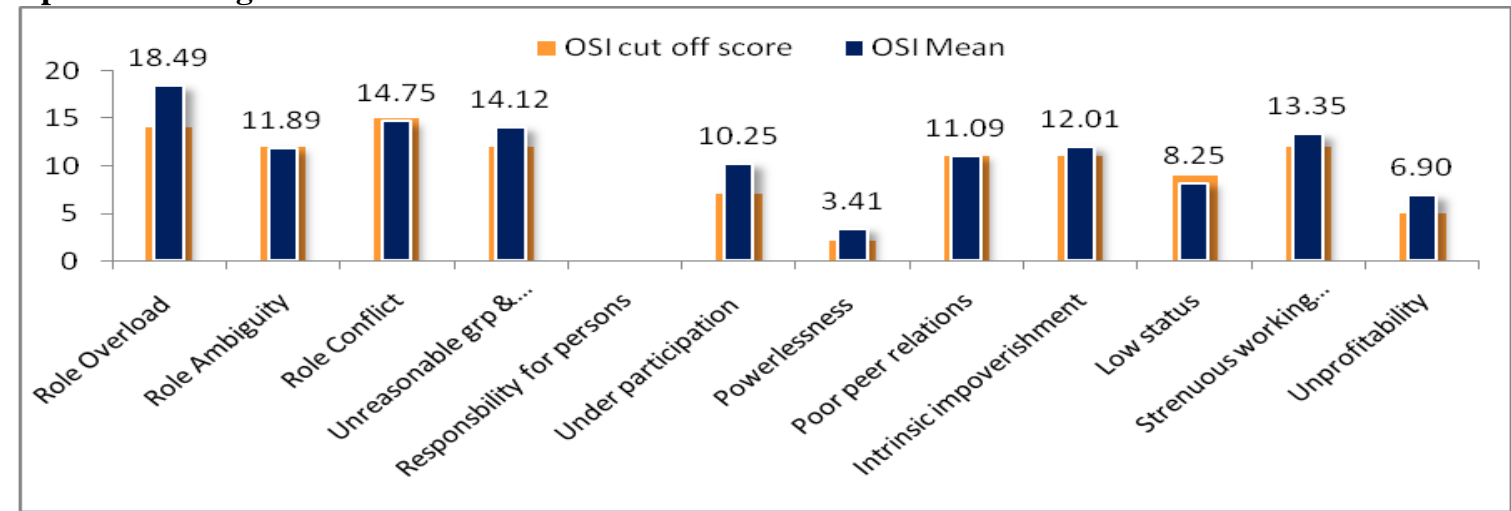

When the average scores are compared with the cut off scores, it is observed that except for the three dimensions- Role ambiguity, Role conflict and Low status, all the other nine dimensions the mean score is higher than the cut off score. This indicated that those 9 dimensions cause stress at a higher degree. Of these dimensions, role overload that has the highest difference from cutoff score. The least difference is for Poor peer relations.

The overall Stress Index has mean score 121.68, much higher than the cut off score 97 indicating a high stress level prevailing among the respondents.

\section{Graph 4: Showing Occupational Stress Index Level, Percentage of Change}

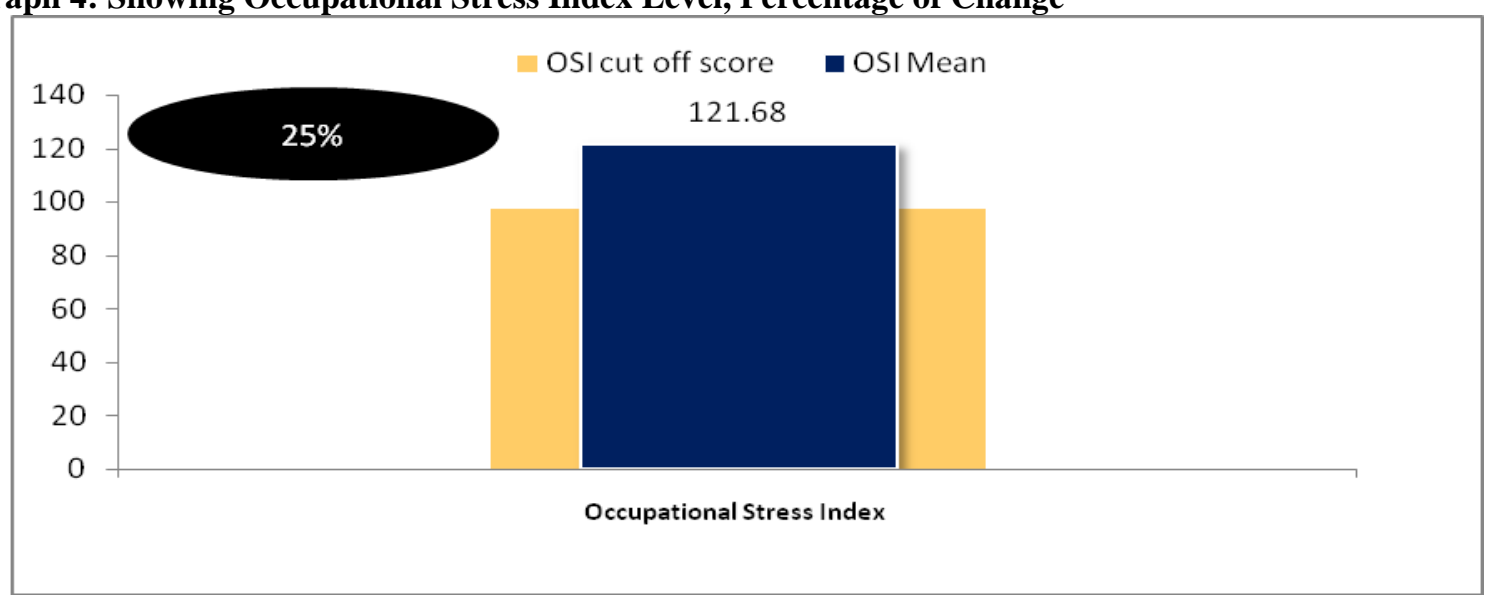

Occupational Stress Index Mean is $25 \%$ more than the cut off score. It means that the HC/PC are experiencing more stress.

\section{Findings}

The results observed from the analysis have demonstrated that among eleven dimensions, except for the four dimensions- Role Conflict (43.2\%), Poor peer relations (42.7\%), Role ambiguity (36.6\%), and Low Status $(32.8 \%)$, all the other seven dimensions the mean score is higher than the cut off score. This indicates that those dimensions cause stress at a higher degree. The seven dimensions are Role Overload $(85.1 \%)$, Unprofitability (83.4\%), Under participation (81.7\%), Powerlessness (72.6\%), Unreasonable group \& political pressure $(65.3 \%)$, Strenuous working conditions $(60.2 \%)$, \& Intrinsic Impoverishment (55.6\%). Of the seven dimensions, role overload that has the highest difference from cutoff score followed by Under participation. The least difference is for Poor peer relations. It means that the stress in police department among $\mathrm{HC} / \mathrm{PC}$ is more mainly because of Role overload, Unprofitability, Under participation, Powerlessness, Unreasonable group \& political pressure, Strenuous working conditions, \& Intrinsic Impoverishment. The overall Stress Index has mean score 121.68, much higher than the cut off score 97 indicating a high stress level, which indicates the stress level is $25 \%$ more than the cutoff score signifying high level of stress.

\section{Discussion And Conclusion}

Out of 11 dimensions, seven dimensions are causing high stress in police department. Those are role overload, unprofitability, under participation, powerlessness, unreasonable group \& political pressure, strenuous working conditions, and intrinsic impoverishment, whose mean score is more than the cut off score. Among these, role overload, unprofitability, underparticipation, powerlessness, unreasonable group and political 
pressure, strenuous working conditions, and intrinsic impoverishment are the main causes for high stress among $\mathrm{HC}$ and PC. Overall occupation stress index has shown $85.5 \%$ high stress in police department, which states that among 475 respondents, 406 respondents are experiencing high stress.

\section{Recommendations}

Stress is inevitable in Police department because of their job profile and nature of work. It is very difficult to make a police department stress free, but few steps can be taken to reduce stress among the employees of police department.

Stress- free work zone - The key factor to creating a stress-free environment for employees is setting clear expectations, having a regular and consistent reward and recognition programme, emphasizing on training and employees development, creating a transparent and open work culture with clear channels of communication - adds up in creating a work environment that is secure and minimizes stress in employees.

Table 10: Showing the Training Programmes to overcome Occupational Stress

A training programme can solve most issues related to stress. A tentative structure has been proposed.

\begin{tabular}{|c|c|c|c|c|c|}
\hline $\begin{array}{l}\text { Sl. } \\
\text { No }\end{array}$ & Dimension & Nature & HC/PC & Syllabus & Method \\
\hline 1. & Role Overload & $\begin{array}{l}\text { 1. Job Analysis } \\
\text { 2. Time Management } \\
\text { 3. Meditation } \\
\text { 4. Yoga } \\
\text { 5. Counseling }\end{array}$ & $\begin{array}{l}4 \text { months/ } \\
2 \text { days }\end{array}$ & $\begin{array}{l}\text { 1.Review formal job documentation } \\
\text { 2.Make them understand about the } \\
\text { Organization's Strategy and Culture } \\
\text { 3. Find out who the top achievers are, and } \\
\text { understand why they are successful } \\
\text { 4. Check you have the people and } \\
\text { resources to do the job } \\
\text { 5. Confirm priorities with your boss }\end{array}$ & $\begin{array}{l}\text { 1.Classroom Lecture } \\
\text { 2.Case study } \\
\text { 3. Role Play }\end{array}$ \\
\hline 2. & $\begin{array}{l}\text { Role } \\
\text { Ambiguity }\end{array}$ & $\begin{array}{l}\text { 1.Decision making } \\
\text { 2.Organising } \\
\text { 3.Communication }\end{array}$ & $\begin{array}{l}4 \text { months } \\
\text { / } 1 \text { day }\end{array}$ & $\begin{array}{l}\text { 1. Making quick decisions without } \\
\text { handful of data which is very dangerous. } \\
\text { Discuss about the impact. } \\
\text { 2. Involve employees in decision making } \\
\text { 3. Make step by step plan. Before } \\
\text { assigning work make a proper set of } \\
\text { instructions about carrying work. } \\
\text { 4. Use better signs and symbols which } \\
\text { are not misinterpreted by the employees } \\
\text { while communicating. }\end{array}$ & $\begin{array}{l}\text { 1.Story telling } \\
\text { 2.Building blocks } \\
\text { 3.Role Play } \\
\text { 4.Small group } \\
\text { exercises on active } \\
\text { listening }\end{array}$ \\
\hline 3. & Role Conflict & $\begin{array}{l}\text { 1.conflict \& work } \\
\text { 2.Emotional } \\
\text { Intelligence }\end{array}$ & $\begin{array}{l}3 \\
\text { months/1 } \\
\text { day }\end{array}$ & $\begin{array}{l}\text { 1.Ask participants what they associate } \\
\text { with conflict } \\
\text { 2.Ask participants to select a conflict } \\
\text { from their own fields of work \& draw a } \\
\text { picture } \\
\text { 3.Discuss about the picture in small } \\
\text { group and ask why conflict raised, \& how } \\
\text { it can be solved } \\
\text { 2.1.Activities based on Appraisal \& } \\
\text { Expression of emotions - verbal, } \\
\text { nonverbal, empathy } \\
\text { 2.Activities based on regulation of } \\
\text { emotions - in self, in others. } \\
\text { 3.Activities based on utilization } \\
\text { emotions- Flexible planning, creative } \\
\text { thinking, redirected attention, motivation. }\end{array}$ & $\begin{array}{l}\text { 1.Brainstorming } \\
\text { 2.Individual exercise } \\
\text { 3.Presentations on } \\
\text { conflict areas } \\
\text { 4. Lecture } \\
\text { 5. Role Play }\end{array}$ \\
\hline 4. & $\begin{array}{l}\text { Unreasonable } \\
\text { group \& } \\
\text { Political } \\
\text { Pressure }\end{array}$ & $\begin{array}{l}\text { 1.Unfair Criticism } \\
\text { 2.Decision making } \\
\text { 3.Handling pressure }\end{array}$ & $\begin{array}{l}6 \\
\text { months/1 } \\
\text { day }\end{array}$ & $\begin{array}{l}\text { 1.Remain calm } \\
\text { 2.Have the point repeated - don't go for } \\
\text { personal clash } \\
\text { 3. Open up both prospective } \\
\text { 4.Move on politely } \\
\text { 5.Maintain self esteem }\end{array}$ & $\begin{array}{l}\text { 1.Role play } \\
\text { 2.Mediatation } \\
\text { 3.Yoga } \\
\text { 4.activities on } \\
\text { communication skills }\end{array}$ \\
\hline 5. & $\begin{array}{l}\text { Under } \\
\text { participation }\end{array}$ & $\begin{array}{l}\text { 1.Self Confidence } \\
\text { 2.verbal and non } \\
\text { verbal presentation } \\
\text { skills } \\
\text { 3.Motivation }\end{array}$ & $\begin{array}{l}3 \\
\text { months/1 } \\
\text { day }\end{array}$ & $\begin{array}{l}\text { 1.Overcoming fear / anxiety } \\
\text { 2.Involving in decision making } \\
\text { 3.Communication skills } \\
\text { 4.Presentation skills } \\
\text { 5. Counseling } \\
\text { 6.Expectancy Theory - Victor Vroom } \\
\end{array}$ & $\begin{array}{l}\text { 1.On stage activities } \\
\text { 2.Group discussions } \\
\text { 3. Individual exercise } \\
\text { 4.Story telling } \\
\text { 5.Presentations } \\
\text { 6.Counseling } \\
\end{array}$ \\
\hline 6. & Powerlessness & $\begin{array}{l}\text { 1.Participation } \\
\text { 2.Difference between } \\
\text { power and authority }\end{array}$ & $\begin{array}{l}6 \\
\text { months/1 } \\
\text { day }\end{array}$ & $\begin{array}{l}\text { 1.Re-thinking power as relationship } \\
\text { building } \\
\text { 2.Coordination }\end{array}$ & $\begin{array}{l}\text { 1.Classroom Lecture } \\
\text { 2. Games on } \\
\text { coordination }\end{array}$ \\
\hline
\end{tabular}




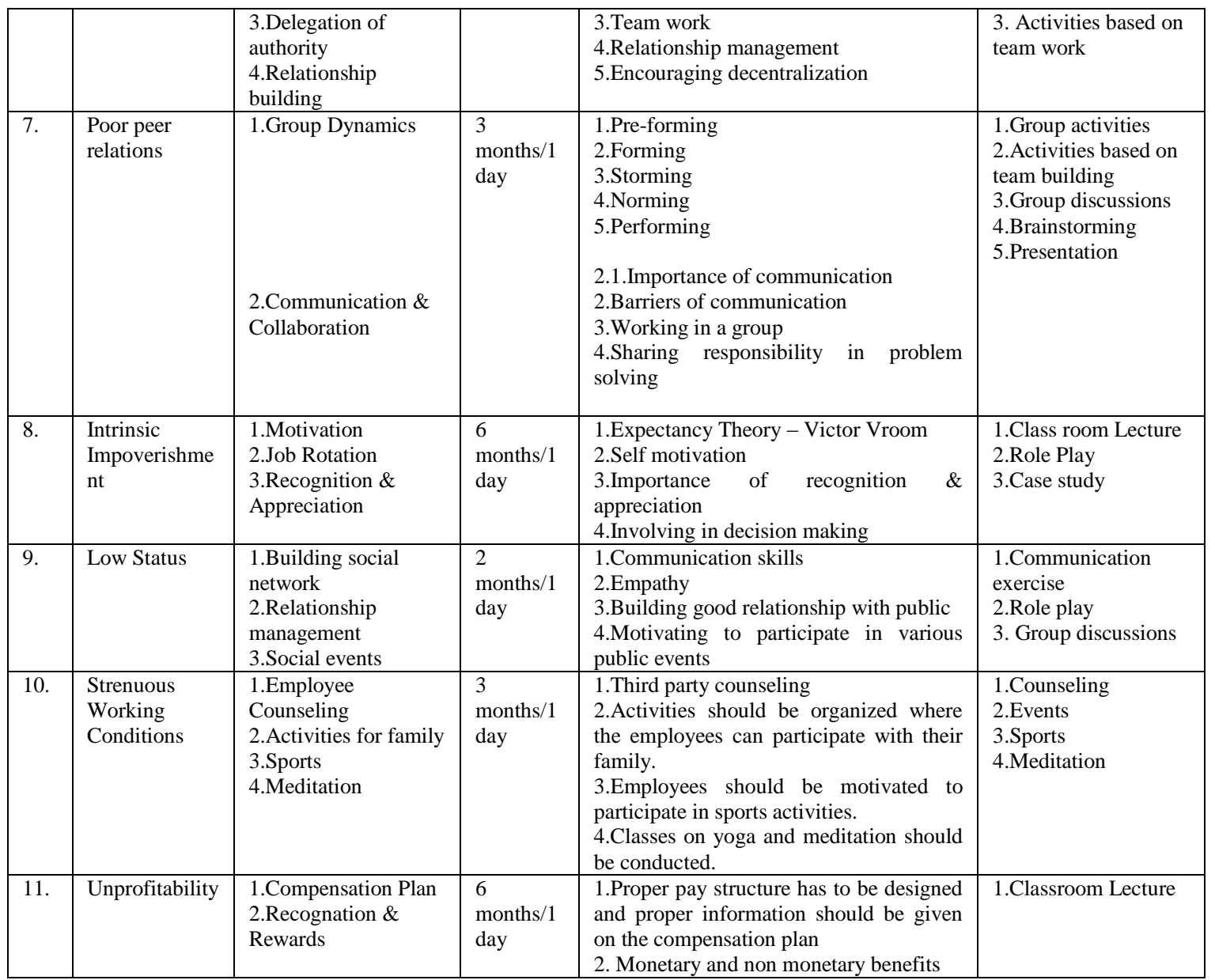

Training is the act of increasing the knowledge and skills of an employee for particular job. The major outcome of training is learning. A trainee learns new habits, refines skills, and useful knowledge during the training that helps him improve performance and prevent stress. An allocation of funds at appropriate time would help to solve stress related issues, per se.

\section{References}

[1] Hans Selye, A syndrome produced by diverse nocuous agents, Nature, 1936, 138, 32

[2] Selye, stress without distress. Philadelphia, PA:J.B.Lippincott, 1974.

[3] Christopher A.Barbb, Police stress: A study of the Melvindale Police Department. An applied research project submitted to the department of interdisciplinary technology as part of the school of police staff and command program. 2003

[4] Peterson D, Organizational Behaviour Issues for Managers, Paper in IIM Ahmedabad, 1995

[5] Upadhayay and Singh, Experience of stress: Differences between college teachers and executives Pshychological Studies, Vol.44, No.3, 1999, pp 19-28

[6] Hasnain N.Z, M.G.Shahanawaz, and V.Shukla, Role stress and coping strategies, J.Com. Gui.Res., Vol.24, No.3, 2001, pp 235-242

[7] Pandey and Tripathy, Occupational stress and burn out in Engineering Teachers, J.Indian Aca.App.Psy., Vol.27, No.1, 2001, pp 6773

[8] Bhattacharya and Guha, stress and coping: A study on lady criminal lawyers of Kolkata city.I.P.R., Special issue 67, 2006, pp 227234

[9] Maria Parkinson, Work place stress - Factors that contribute to work place stress, Enzime Articles, 2010

[10] Barbara B.Reinhold, Toxic work. ED.D, Dutton, 1996.

[11] Sibnath Deb, Tanushree Chakraborty, Pooja Chatterjee, and Neerajakshi Srivatava, Job related stress, causal factors and coping strategies of Traffic Constables, Journal of the Indian Academy of Applied Psychology, Vol.34, No.1, 2008, pp 19-28

[12] NIOSH working group, Police stress research, The Indian Police Journal, 2004. 